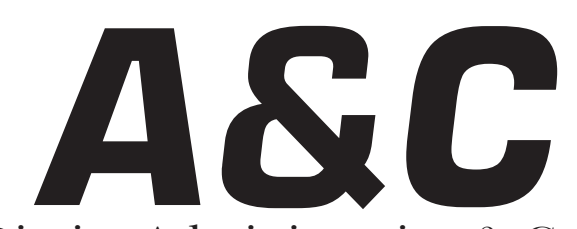

Revista de Direito Administrativo \& Constitucional

Editora Fórum

ISSN 1516-3210

\begin{tabular}{|l|l|l|l|l|l|}
\hline A\&C R. de Dir. Administrativo \& Constitucional & Belo Horizonte & ano 8 & n. 32 & p. 1-256 & abr.jun. 2008 \\
\hline
\end{tabular}




\section{A\&C REVISTA DE DIREITO ADMINISTRATIVO \& CONSTITUCIONAL}

IPDA

Instituto Paranaense

de Direito Administrativo

Direção Geral

Romeu Felipe Bacellar Filho

Direção Editorial

Paulo Roberto Ferreira Motta

Direção Executiva

Emerson Gabardo

Conselho de Redação

Edgar Chiuratto Guimarães

Adriana da Costa Ricardo Schier

Célio Heitor Guimarães

\section{Conselho Editorial}

Jorge Luís Salomoni - in memoriam (Argentina)

José Carlos Abraão (Brasil)

José Eduardo Martins Cardoso (Brasil)

José Luís Said (Argentina)

José Mario Serrate Paz (Uruguai)

Juan Pablo Cajarville Peruffo (Uruguai)

Juarez Freitas (Brasil)

Julio Rodolfo Comadira - in memoriam (Argentina)

Luís Enrique Chase Plate (Paraguai)

Lúcia Valle Figueiredo (Brasil)

Manoel de Oliveira Franco Sobrinho -

in memoriam (Brasil)

in memoriam (Brasil)

Marçal Justen Filho (Brasil)

Marcelo Figueiredo (Brasil)
Márcio Cammarosano (Brasil)
Maria Cristina Cesar de Oliveira (Brasil)

Nelson Figueiredo (Brasil)

Odilon Borges Junior (Brasil)

Pascual Caiella (Argentina)

Paulo Eduardo Garrido Modesto (Brasil)

Paulo Henrique Blasi (Brasil)

Paulo Neves de Carvalho - in memoriam

(Brasil)

Paulo Ricardo Schier (Brasil)

Pedro Paulo de Almeida Dutra (Brasil)

Regina Maria Macedo Nery Ferrari (Brasil)

Rogério Gesta Leal (Brasil)

Rolando Pantoja Bauzá (Chile)

Sérgio Ferraz (Brasil)

Valmir Pontes Filho (Brasil)

Yara Stropa (Brasil)

Weida Zancaner (Brasil)

A246 A\&C Revista de Direito Administrativo \& Constitucional. ano 3, n. 11, jan./mar. 2003. Belo Horizonte: Fórum, 2003.

Trimestral

ano 1, n. 1, 1999 até ano 2, n. 10, 2002 publicada

pela Editora Juruá em Curitiba

ISSN 1516-3210

1. Direito Administrativo. 2. Direito Constitucional.

I. Fórum.

CDD: 342 CDU: 33.342

(C) Editora Fórum Ltda. 2008

Todos os direitos reservados. É proibida a reprodução total ou parcial, de qualquer forma ou por qualquer meio eletrônico ou mecânico, inclusive através de processos xerográficos, de fotocópias ou de gravação, sem permissão por escrito do possuidor dos direitos de cópias (Lei n 9.610, de 19.02.1998).

Editora Fórum Ltda

Av. Afonso Pena, 2770 - 15\%16 andar - Funcionários

CEP 30130-007 - Belo Horizonte/MG - Brasil

Tel.: 08007043737

Internet: www.editoraforum.com.br

e-mail: editoraforum@editoraforum.com.br
Editor responsável: Luís Cláudio Rodrigues Ferreira Coordenação editorial: Olga M. A. Sousa

Pesquisa jurídica: Fátima Ribeiro - OAB/MG 74868

Revisora: Lourdes Nascimento

Projeto gráfico: Luis Alberto Pimenta

Diagramação: Marcelo Belico

Bibliotecária: Fernanda de Paula Moreira -

CRB 2900 - 6a região

Os conceitos e opiniões expressas nos trabalhos assinados são de responsabilidade exclusiva de seus autores.

Impressa no Brasil / Printed in Brazil

Distribuída em todo o Território Nacional 


\title{
Jurisdição constitucional, democracia e liberdade de expressão: análise do caso Ellwanger
}

\author{
Cláudia Honório* \\ Especialista em Direito Constitucional pela UniBrasil. Mestranda em Direito do Estado pela \\ Universidade Federal do Paraná. Bolsista da Capes.
}

Heloísa Krol**

Mestre e Doutoranda em Direito do Estado pela Universidade Federal do Paraná.

Resumo: O presente artigo analisa a relação entre jurisdição constitucional, democracia e liberdade de expressão em um contexto democrático. Para analisar essa relação, foi escolhido o paradigmático "caso Ellwanger", julgado pelo Supremo Tribunal Federal brasileiro em 2003.

Palavras-chave: Jurisdição constitucional. Liberdade de expressão. Democracia.

Sumário: Introdução - 1 A jurisdição constitucional no Estado Democrático de Direito - 2 O caso Ellwanger - 3 Os votos dos Ministros do Supremo Tribunal Federal - 4 A liberdade de expressão num contexto democrático - 5 Considerações finais - Referências

\section{Introdução}

Em um Estado Democrático de Direito, a jurisdição constitucional revela-se importante para tutelar os direitos fundamentais. Mas tal tutela ou sua medida — não é pacífica nem simples, tendo em vista que a atuação jurisdicional pode significar a desqualificação de decisões tomadas pela maioria no exercício da democracia. Considerando esse aspecto, pode o Poder Judiciário restringir legitimamente o direito fundamental à liberdade de expressão de um indivíduo, garantia firmada pelo pacto constitucional e imprescindível para o debate democrático? Ganha relevo a análise do caso Ellwanger, julgado pelo Supremo Tribunal Federal em 2003, em que se decidiu, no contexto da democracia brasileira, que pressupõe a liberdade de expressão, pela limitação dessa liberdade, sob a alegação de justamente preservar a democracia. Assim, aos temas jurisdição constitucional, democracia e liberdade de expressão dedica-se o presente artigo.

\footnotetext{
*E-mail: <adv_claudiah@yahoo.com.br>.
}

**E-mail: <helo_krol@hotmail.com>. 


\section{A jurisdição constitucional no Estado Democrático de Direito}

Entre as instituições consagradas pelo Estado de Direito - que tem como corolários a idéia de limitação e contenção do poder estatal pela consagração dos direitos fundamentais e da separação das funções estatais - a de relação mais problemática com a democracia é a jurisdição constitucional.

A incômoda relação se dá por vários motivos. Primeiro, porque dos “poderes” estatais, o Judiciário é o que tem a mais problemática relação com a base democrática, tendo em vista que de regra não há uma participação direta do povo nas suas deliberações e também os seus membros não são escolhidos pelo voto popular. Ainda, os juízes não estão sujeitos à renovação periódica dos seus "mandatos" e não são diretamente responsáveis perante a opinião pública. ${ }^{1}$ Não se está afirmando que a melhor forma de resolver a questão seja promover eleições para juízes, por exemplo, pois isso poderia comprometer a necessária imparcialidade exigida da função. Mas não se pode ignorar que essas características acarretam um déficit de legitimidade democrática da jurisdição constitucional.

Contudo, existem fortes argumentos que legitimam a atuação da jurisdição constitucional. $\mathrm{O}$ argumento clássico foi desenvolvido pelo federalista Hamilton² e retomado na seqüência por Marshall no julgamento do caso Marbury us Madison ${ }^{3}$ no sentido de que o Judiciário simplesmente

\footnotetext{
${ }^{1}$ NINO. La constitucion de la democracia deliberativa, p. 258-259.

${ }^{2} \mathrm{Na}$ sua argumentação a favor da atuação dos juízes como guardiões da Constituição, Hamilton sustentou que quando o Judiciário reprime leis inconstitucionais não está se sobrepondo ao Legislativo, mas apenas está afirmando a superioridade do poder do povo expressa na Constituição. Ainda, Hamilton defendeu que "até que o povo tenha, por algum ato solene e peremptório, anulado ou alterado as normas vigentes, elas devem ser obedecidas tanto coletiva como individualmente e nenhum pressuposto ou mesmo conhecimento das intenções do povo poderá autorizar seus representantes a furtarem-se, antes do referido ato, ao cumprimento daquelas normas" (HAMILTON. Os juízes como guardiões da constituição. In: HAMILTON; MADISON; JAY. O federalista, p. 578-580).

${ }^{3} \mathrm{O}$ caso Marbury v. Madison é tido como precursor do controle difuso-incidental de constitucionalidade. Em síntese, o caso consiste no seguinte: William Marbury foi designado juiz pelo então presidente John Adams na véspera deste deixar o cargo. Todavia, Thomas Jefferson, presidente que assumiu na seqüência, decidiu não reconhecer as designações enviadas pela administração de Adams. Então, Marbury ingressou com "writ of mandamus" na Suprema Corte norte-americana para que se ordenasse James Madison, então Secretário de Estado, que o empossasse como juiz de paz com base na seção 13 do "Judiciary Act" de 1789. No entanto, em 1802, o Congresso revogou o "Judiciary Act". Então, ciente de que se fosse concedido o mandado a decisão poderia não ser cumprida, Marshall estabeleceu que Marbury tinha direito de ser empossado, tendo em vista que a nomeação era irrevogável. Mas negou que a Suprema Corte poderia julgar o caso, pois a seção 13 do "Judiciary Act" que lhe atribuía tal competência era inconstitucional na medida em que ampliava a competência da Suprema Corte estabelecida constitucionalmente. Assim, Marshall sustentou o poder do Judiciário de invalidar atos legislativos inconstitucionais tendo em vista a supremacia constitucional. Para uma análise do caso e da semelhança com os argumentos de Hamilton: MORO. Jurisdição constitucional como democracia, p. 09-10; GARGARELLA. La justicia frente al gobierno: sobre el carácter contramayoritario del poder judicial, p. 44-47. Para uma síntese dos fundamentos e importância do julgado na história constitucional: FARBER; ESKRIDGE JUNIOR; FRICKEY. Constitutional law: themes for the constitution's third century, p. 61-74.
} 
assegura o que está previsto na Constituição e, portanto, é a "vontade constitucional" que se impõe na decisão das questões constitucionais, não a "vontade dos juízes".

Outra linha de argumentação muito próxima desenvolve-se a partir do trabalho de John Rawls, que entende a jurisdição constitucional como instituição legítima para proteger os elementos constitucionais essenciais. ${ }^{4}$ Para Rawls, quando não estão em questão os elementos constitucionais essenciais, as maiorias podem decidir de acordo com determinada doutrina abrangente. Porém a jurisdição constitucional não tem essa abertura, pois o Judiciário não pode invocar a sua moralidade particular para decidir, devendo se limitar aos valores políticos de justiça e à razão pública e, por isso, o Judiciário é definido por Rawls como um caso exemplar de razão pública. ${ }^{5}$

Mas note-se que o próprio Rawls não justifica porque o Judiciário seria a instituição legítima para fazer valer os elementos constitucionais essenciais em todos os planos, embora afirme que o Judiciário é o melhor intérprete da Constituição. ${ }^{6}$

De fato, a questão da atuação da jurisdição constitucional não é simples. Antes de se tomar qualquer posição, deve-se enfrentar necessariamente a objeção contramajoritária, tratada de forma bastante minuciosa por

\footnotetext{
${ }^{4}$ Os elementos constitucionais essenciais em Rawls referem-se aos princípios que especificam a estrutura geral do Estado e do processo político e os direitos e liberdades fundamentais. Portanto, abarca o primeiro princípio da justiça enunciado da seguinte forma: todas as pessoas têm igual direito a um projeto inteiramente satisfatório de direitos e liberdades básicas iguais para todos, projeto este compatível com todos os demais; e, nesse projeto, as liberdades políticas deverão ter seu valor eqüitativo garantido. Assim, o primeiro princípio da justiça deve ser concretizado no nível constitucional e o segundo no nível legislativo, sendo que este é dessa forma enunciado: as desigualdades econômicas e sociais devem satisfazer dois requisitos: a) primeiro, devem estar vinculadas a posições e cargos abertos a todos, em condições de igualdade eqüitativa de oportunidades; e, b) segundo, devem representar o maior beneficio possível aos membros menos privilegiados da sociedade. Para Rawls, embora os dois princípios da justiça sejam objeto de um consenso sobreposto, a garantia do segundo princípio deve se dar argumentativamente e apenas o primeiro se realizar no âmbito constitucional. Mas note-se que Rawls entende o mínimo vital como um elemento constitucional essencial, bem como as garantias materiais necessárias para que os direitos políticos tenham um valor eqüitativo (RAWLS. O liberalismo político, p. 47-48, 277-280)

${ }^{5}$ A razão pública é definida por Rawls como a razão dos cidadãos, que tem por objeto o bem público e as questões de justiça fundamental; e sua natureza e conceito são púbicos, sendo determinados pelos ideais e princípios expressos pela concepção de justiça política da sociedade conduzidos à vista de todos sobre essa base. O ideal de razão pública se aplica aos cidadãos e aos fóruns oficiais do Estado, mas, de forma especial, ao Judiciário porque os juizes têm que explicar e justificar suas decisões baseadas em sua compreensão da Constituição, de estatutos, precedentes, diferente dos atos do legislativo e do executivo. Então, o papel especial do Judiciário faz dele um caso exemplar de razão pública (RAWLS, op. cit., p. 262-264, 281-290).

${ }^{6}$ RAWLS, op. cit., p. 283. O autor recorre inclusive a um argumento muito próximo ao desenvolvido por Hamilton e Marshall, afirmando que "o tribunal não é antimajoritário com respeito à lei mais alta quando suas decisões estão razoavelmente de acordo com a constituição em si, com as emendas feitas a ela e com as interpretações politicamente determinadas" (Ibid., p. 283).
}

A\&C R. de Dir. Administrativo \& Constitucional, Belo Horizonte, ano 8, n. 32, p. 77-92, abr./jun. 2008 
Roberto Gargarella, pois não é tão claro porque o Judiciário deve atuar como guardião da Constituição.

Gargarella analisa as denominas "soluções conservadoras" que procuram justificar a atuação da jurisdição constitucional. ${ }^{7} \mathrm{O}$ primeiro argumento para justificar que os juízes decidam em nome do povo assenta-se na noção de que a imparcialidade pode ser prejudicada pelo apelo constante à cidadania, na medida em que se poderia decidir com base em opiniões precipitadas, prejudiciais ou pouco refletidas. ${ }^{8}$

Assim, a legitimidade da jurisdição constitucional estaria baseada em um argumento profundamente elitista: os juízes, por estarem afastados do calor do debate público e por serem indivíduos extremamente capacitados em relação aos membros do Executivo e do Legislativo, poderiam decidir em última instância sobre as questões constitucionais mais fundamentais e também sobrepor a sua opinião sobre a opinião do Legislativo. ${ }^{9}$

Gargarella observa que os defensores do controle jurisdicional da constitucionalidade buscam contornar esse argumento afirmando, por exemplo, que quando o Judiciário nega validade a uma lei não está impondo a sua opinião sobre a vontade do povo, mas apenas sobrepondo o que está determinado na Constituição. Trata-se, aliás, de uma das mais sólidas e difundidas defesas do controle de constitucionalidade presentes já na tese de Hamilton. ${ }^{10}$

Todavia, insiste Gargarella que também não é tão evidente assim que o Judiciário esteja apenas afirmando o estabelecido constitucionalmente pelo povo, por vários motivos. Primeiramente, há que se aferir o grau de adesão do povo à própria Constituição, tendo em vista exemplos históricos de Constituições até hoje vigentes que foram promulgadas sem que boa parte da população fosse considerada como integrante do povo. ${ }^{11}$

${ }^{7}$ GARGARELLA, op. cit., p. 48.

${ }^{8}$ De fato, não se nega que sustentar a legitimidade da jurisdição constitucional a partir dessa premissa consistiria em veicular um argumento profundamente elitista. Mas também não se pode desconsiderar que é muito difícil deixar questões a exclusiva solução popular em momentos de profundo clamor público. Clèmerson Merlin Clève trabalha sempre com o exemplo de que no atual contexto brasileiro caso realizado um plebiscito ou referendo para consultar os cidadãos sobre a possibilidade de instituição da pena de morte essa seria aprovada mesmo diante da consagração como direito fundamental do direito à vida (CLÈVE. Palestra. In: Discurso e direito: discursos do direito). Também, Carlos Santiago Nino analisa importantes momentos nos quais se recorreu a mecanismos de democracia direita como o plebiscito que legitimou em 1958 a retirada da França da Argélia, mas reconhece que há muitos riscos em trabalhar com esses instrumentos tais como a possibilidade de manipulação e captação dos cidadãos (NINO, op. cit., p. 206).

${ }^{9}$ GARGARELLA, op. cit., p. 50-51.

${ }^{10}$ Ibid., p. 53. Conferir também MORO, op. cit., p. 95-100.

A\&C R. de Dir. Administrativo \& Constitucional, Belo Horizonte, ano 8, n. 32, p. 77-92, abr./jun. 2008 
Em segundo lugar, também é difícil sustentar porque a manifestação de vontade da geração anterior deveria se sobrepor às manifestações de vontade das gerações presentes e às futuras manifestações das gerações sobre as questões políticas. Ou, o que justificaria a imposição de ataduras pelas gerações passadas? $^{12}$

Também, não se pode aceitar que o papel da jurisdição constitucional restrinja-se à mera leitura do que está expresso na Constituição. A redação dos dispositivos constitucionais em geral admite uma interpretação

${ }^{11}$ Gargarella trabalha com o exemplo da Constituição norte-americana que foi promulgada com a exclusão de boa parte do povo norte-americano do conceito de cidadão, como os escravos, os negros, as mulheres e os que não tinham uma posição econômica relevante (GARGARELLA, op. cit., p. 54). Da mesma forma, a Constituição argentina de 1853, sancionada em um momento que várias exclusões eram aceitas. Sobre o tema: NINO. Fundamentos de derecho constitucional: análisis filosófico, jurídico y politológico de la práctica constitucional, p. 32-36.

12 A questão intertemporal das imposições constitucionais foi objeto de preocupação de Jon Elster. Como uma possível solução para esse problema, Elster recorreu à metáfora de Ulisses, embora tenha reconhecido na seqüência que é válida apenas parcialmente para explicar a atividade constituinte. A metáfora de Ulisses, que determina que o amarrem ao mastro da embarcação para não sucumbir ao canto das sereias, explicaria o papel das restrições constitucionais em uma sociedade democrática, ou seja, demonstra como se impedir que a própria constituição sucumba diante de paixões, desejos passageiros, miopias das maiorias. Assim, Elster definiu as constituições como mecanismos de pré-compromisso que servem para proteger contra decisões imprudentes. Portanto, o papel das limitações constitucionais seria o de impedir que a sociedade modifique sua opinião em questões importantes baseada apenas em paixões, auto-engano e histerias que podem determinar que uma maioria temporal estabeleça alterações lamentadas posteriormente. Em outros termos, as restrições constitucionais se prestariam a proteger as sociedades democráticas das miopias crônicas (ELSTER. Ulises desatado: estudios sobre a racionalidad, precompromisso y restricciones, p. 115; ELSTER. Introducción. In: ELSTER; SLAGSTAD (Org.). Constitucionalismo y democracia, p. 41). No entanto, perceba-se que a analogia com Ulisses não é de todo apropriada para justificar a autovinculação das gerações. Primeiro, porque as constituições, mais do que se apresentarem como atos de auto-restrição, atam e impõem restrições aos demais e, por outro lado, pode ocorrer que uma constituição inclusive não tenha poder para restringir. $\mathrm{O}$ próprio Elster reformulou algumas noções diante da crítica de Jens Arup Seip, que afirmou que "na política, a gente nunca trata de atar-se a si mesmo, mas sim de atar aos demais". Apesar da severidade da crítica, Elster reconheceu que acaba se aproximando mais da verdade do que a concepção de que se auto-impor restrições seja a essência da elaboração de uma constituição (ELSTER, Ulises desatado..., p. 11, 115). No mesmo sentido, Oscar Vilhena Vieira observa que no caso de Ulisses ocorre uma limitação individual, ao passo que no processo constitucional a rigidez imposta tem um caráter supra-individual, na medida em que é imposta ao conjunto da sociedade. Ainda, pondera que o modelo de pré-cometimento constitucional se distingue da autovinculação de Ulisses, tendo em vista que os mecanismos constitucionais tradicionais não estabelecem uma vedação total à liberdade de ação dos parlamentos, mas apenas as cláusulas que denomina de superconstitucionais (VIEIRA. A constituição e sua reserva de justiça: um ensaio sobre os limites materiais ao poder de reforma, p. 15, 20). Também, Stephen Holmes analisa e refuta a tese de Thomas Schelling, muito próxima da sustentada por Elster, no sentido de que as constituições são estratégias indiretas de mando de uma comunidade. Rejeita porque as nações não são como "indivíduos grandes" e as constituições não podem ser comparadas às promessas de ano novo. Embora Holmes reconheça que o autopaternalismo é uma categoria muito útil para ilustrar a função das restrições constitucionais, aponta três importantes desanalogias entre constitucionalismo e domínio de si mesmo. Primeiro, diferente dos indivíduos que se atam para limitar sua própria capacidade pré-existente de eleição, as constituições estabelecem um procedimento de decisões em lugar de restringir uma vontade pré-existente. De fato, criam um marco em que a nação pode ter uma vontade. Segundo, diferente do homem obeso que se ata porque não dispõe de fortaleza de vontade, a política constitucional não se baseia nesta ambição de virtude. Por fim, enquanto as regras de auto-incapacitação tem apenas um propósito, as normas constitucionais têm diversos e se prestam a favorecer metas futuras ainda desconhecidas dos constituintes (HOLMES. El precompromiso y la paradoja de la democracia. In: ELSTER; SLAGSTAD (Org.). Constitucionalismo y democracia, p. 259-260).

13 Para Gargarella, a partir da "brecha interpretativa" os juízes acabariam tomando o lugar que deveria ser da 
bastante ampla e não automática e por que motivo à delimitação do âmbito normativo da Constituição deveria ficar a cargo do Judiciário ${ }^{13}$

Ainda, a partir da sua concepção democrático-deliberativa, Carlos Santiago Nino afirma que o controle da constitucionalidade é sim imprescindível, contudo, não deve ser necessariamente jurisdicional. ${ }^{14}$ Portanto, o controle jurisdicional da constitucionalidade seria contingente mesmo em um ambiente marcado pela idéia de supremacia constitucional. O controle jurisdicional seria justificável apenas em algumas questões relativas à preservação os direitos fundamentais, frente às deliberações democráticas. ${ }^{15}$

E dentro desse núcleo mínimo que deve necessariamente ser defendido de forma ativa pelo Judiciário estão inseridos aqueles direitos fundamentais que são tidos como condições para a democracia. Para além da proteção desses direitos, devem ser observadas as condições democráticas, pontuando-se em cada caso se é legitima uma postura ativa ou de deferência do Judiciário.

Os direitos tidos como essenciais à democracia são identificados por Nino como os direitos relativos à participação livre e igual no processo de discussão e tomada de decisões, à orientação da comunicação no sentido da justificação, à proteção das minorias isoladas e à proteção de um marco emocional apropriado para a argumentação. ${ }^{16}$ Portanto, na guarda desses direitos fundamentais o Judiciário deve apresentar uma postura mais ativa mesmo no controle abstrato da constitucionalidade, pois a sua atuação reveste-se de evidente legitimidade.

A liberdade de expressão, consagrada no artigo $5^{\circ}$, incisos IV, VIII e IX da Constituição Federal, configura-se como condição indispensável para a democracia, pois assegura a participação livre e igual no processo de discussão e tomada de decisões, e também se presta à proteção das minorias que não serão submetidas à decisão majoritária sem livremente expressar

vontade popular. O autor analisa propostas interpretativas que buscam justificar porque a última palavra sobre questões tão importantes deveria ficar a cargo do Judiciário, mas entende todas como inconsistentes e problemáticas (GARGARELLA, op. cit., p. 57-80).

${ }^{14}$ Para Nino, é difícil aceitar a legitimidade da jurisdição constitucional para dizer a última palavra sobre as questões constitucionais, dirimir os conflitos entre os poderes, interpretar as regras referidas ao procedimento democrático e, principalmente, para definir o alcance dos direitos fundamentais devido ao caráter essencialmente "aristocrático" do órgão, e por suas decisões não gozarem do mesmo valor epistêmico que as decisões de caráter democrático (NINO, La constitucion de la democracia deliberativa..., p. 259-260).

15 lbid., p. 269.

16 lbid., p. 192

${ }^{17}$ Interessante ressaltar que o conceito é constitucional. Nesse sentido, pertinente a observação do Ministro Mo- 
seu ponto de vista e o dissenso.

Portanto, mesmo com base no prisma democrático-deliberativo - que implica em um âmbito mais restrito de atuação da jurisdição constitucional - para garantir a liberdade de expressão é legítima uma postura ativa do Judiciário. Daí se torna interessante a análise do paradigmático caso Ellwanger, julgado em 2003 pelo Supremo Tribunal Federal, momento em que a Corte não tratou de proteger, mas sim de restringir o direito fundamental à liberdade de expressão por razões morais e jurídicas.

\section{0 caso Ellwanger}

Em 14.11.91, Sigfried Ellwanger, autor, editor e distribuidor de livros, foi denunciado pelo crime de racismo contra o povo judeu. Apesar de absolvido em primeira instância, foi condenado pelo Tribunal de Justiça do Rio Grande do Sul a dois anos de reclusão (com sursis pelo prazo de quatro anos), por fazer apologia, por meio de livros, de idéias discriminatórias contra a comunidade judaica, sendo incurso no artigo 20 da Lei $\mathrm{n}^{\mathrm{o}}$ 7.716/89, na redação dada pela Lei no 8.081/90: "Art. 20 - Praticar, induzir ou incitar, pelos meios de comunicação social ou por publicação de qualquer natureza, a discriminação ou preconceito de raça, religião, etnia ou procedência nacional. Pena: reclusão de dois a cinco anos."

Considerou-se que nas obras de sua autoria ("Holocausto. Judeu ou alemão?: nos bastidores da mentira do século") e de sua distribuição ("O judeu internacional", "A história secreta do Brasil", "Brasil: colônia de banqueiros", "Os protocolos dos sábios de Sião", "Hitler: culpado ou inocente?”, "Os conquistadores do mundo: os verdadeiros criminosos de guerra”) há mensagens anti-semitas, racistas e discriminatórias, incitando desprezo e ódio contra os judeus, ao negar o holocausto e afirmar que o povo judeu causa males ao mundo.

Inconformado com a decisão do Tribunal, o réu impetrou habeas corpus perante o Superior Tribunal de Justiça, não obtendo sucesso, devido à imprescritibilidade do crime cometido. Novamente impetrou habeas corpus ( $\left.\mathrm{n}^{\circ} 82.424 / \mathrm{RS}\right)$, dessa vez ante o Supremo Tribunal Federal, alegando não ter cometido crime de racismo, mas simples discriminação, uma vez que os judeus são um povo, não uma raça, como eles mesmos definem. Por não se caracterizarem como raça, não houve racismo, e já estaria prescrito o delito.

A\&C R. de Dir. Administrativo \& Constitucional, Belo Horizonte, ano 8, n. 32, p. 77-92, abr./jun. 2008 
Coube, então, aos Ministros do Supremo Tribunal Federal a análise das seguintes questões: o crime de racismo e, por conseguinte, a imprescritibilidade, dirige-se apenas à discriminação em relação aos negros? A discriminação contra judeus pode ser entendida como racismo? O crime praticado pelo autor é imprescritível?

Os Ministros foram em busca de um conceito jurídico para a expressão "racismo" contida na Constituição Federal. Isso porque, como notou a Ministra Ellen Gracie, a Carta não adotou nenhum conceito extrajurídico de forma exclusiva, mas elaborou conceito próprio, ${ }^{17}$ normativo.

Nessa busca, suscitou-se o importante tema da liberdade de expressão. Sigfried Ellwanger não estaria apenas exercendo seu direito fundamental à livre expressão de suas idéias? Num Estado Democrático de Direito, como é o Estado Brasileiro, que tem por fundamento o pluralismo político, é correto condenar alguém porque propagou suas idéias? Enfim, pode o Judiciário calar discursos?

\section{Os votos dos Ministros do Supremo Tribunal Federal}

Cabe analisar os votos dos Ministros do Supremo Tribunal Federal, proferidos no julgamento em exame, que suscitaram o tema da liberdade de expressão.

Os Ministros reconhecem que a liberdade de expressão não é absoluta, e sim comporta limites estabelecidos pelo próprio ordenamento jurídico e pela moral. Contudo, divergem em relação à decisão a ser dada ao caso concreto, e trazem importantes questões.

O Ministro Celso de Mello, que votou pela denegação da ordem no habeas corpus, expressou que a liberdade de expressão é importante, mas não absoluta, encontrando limites na igualdade e na dignidade. A liberdade, para ele, não abrange incitação ao ódio. Assim, não se pode falar que no caso em apreço houve colisão entre a dignidade do povo judeu e a liberdade de expressão do paciente, pois a conduta praticada por ele nem mesmo adentra a esfera da liberdade de expressão. ${ }^{18}$

reira Alves: "A expressão 'nos termos da lei', que se encontra na parte final desse dispositivo da Constituição, não delega à legislação ordinária dar o entendimento que lhe aprouver sobre o significado de 'racismo', mas, sim, que cabe a ela tipificar as condutas em que consiste essa prática e quantificar a pena de reclusão a elas cominada" (SUPREMO TRIBUNAL FEDERAL. Crime de racismo e anti-semitismo: um julgamento histórico no STE: habeas corpus no $82.424 /$ RS, p. 14).

${ }_{18}$ Aqui resta evidente a adoção da teoria dos limites imanentes dos direitos fundamentais. segundo Martin 
O Ministro Gilmar Mendes também votou pela denegação da ordem. Expressou que a discriminação racial levada a efeito pelo exercício da liberdade de expressão compromete um dos pilares da democracia, que é a igualdade. Afirmou que no presente caso instaurou-se uma colisão entre direitos fundamentais, que deveria ser resolvida mediante o emprego do princípio da proporcionalidade:

É evidente a adequação da condenação do paciente para se alcançar o fim almejado, qual seja, a salvaguarda de uma sociedade pluralista, onde reine a tolerância. (...) Também não há dúvida de que a decisão condenatória, tal como proferida, seja necessária, sob o pressuposto de ausência de outro meio menos gravoso e igualmente eficaz. (...) A decisão atende, por fim, à proporcionalidade em sentido estrito. Nesse plano, é necessário aferir a existência de proporção entre o objetivo perseguido, qual seja, a preservação dos valores inerentes a uma sociedade pluralista, da dignidade humana, e o ônus imposto à liberdade de expressão do paciente. Não se contesta, por certo, a proteção conferida pelo constituinte à liberdade de expressão. Não se pode negar, outrossim, o seu significado inexcedível para o sistema democrático. Todavia, é inegável que essa liberdade não alcança a intolerância racial e o estímulo à violência, tal como afirmado no acórdão condenatório. Há inúmeros outros bens jurídicos de base constitucional que estariam sacrificados na hipótese de se dar uma amplitude absoluta, intangível, à liberdade de expressão na espécie. ${ }^{19}$

Assim, entendeu prevalecerem, no caso concreto, a dignidade da pessoa humana, o pluralismo político, o repúdio ao racismo e a imprescritibilidade, sendo restringida a liberdade de expressão.

Para o Ministro Carlos Velloso, que igualmente votou pela denegação da ordem, a conduta de Sigfried Ellwanger foi criminosa, não encontrando amparo na liberdade de expressão, pois afronta o princípio da dignidade da pessoa humana. O Ministro Nelson Jobim trouxe a importante questão de que as idéias preconceituosas não contribuem para o debate democrático, e por isso votou também pela denegação da ordem.

Na mesma esteira o voto do Ministro Maurício Corrêa, pela denegação da ordem, afirmando que a liberdade de expressão não assegura

Borowski, duas teorias para explicar o fenômeno da restrição dos direitos fundamentais. A primeira é a teoria externa. Em um momento inicial existe um direito ilimitado prima facie; então, incide uma restrição sobre esse direito; dessa intervenção se obtém o direito definitivo delimitado. A segunda teoria é a teoria interna, segundo a qual desde o início o direito é pensado com um determinado conteúdo. Por essa perspectiva, determinada possibilidade se encontra de antemão excluída da proteção da norma. Nessa concepção, não há possibilidade de restrição de direito, porque toda restrição já é inerente ao direito (fala-se em limites imanentes), não algo externo (BOROWSKI. La estructura de los derechos fundamentales, p. 66-70).

19 SUPREMO TRIBUNAL FEDERAL, op. cit., p. 76-77.

${ }^{20}$ BRASIL. Supremo Tribunal Federal. HC 82424/RS. Relator: Ministro Maurício Corrêa. 17 set. 2003. Diário de

A\&C R. de Dir. Administrativo \& Constitucional, Belo Horizonte, ano 8, n. 32, p. 77-92, abr./jun. 2008 
o direito à incitação ao racismo. E o voto do Ministro Cezar Peluso, para quem o paciente procurou promover e difundir o anti-semitismo, o que contraria a tutela constitucional dos grupos sociais diferenciáveis e transpõe os limites da liberdade de expressão.

Em sentido contrário, o Ministro Carlos Britto defendeu a concessão da ordem, sustentando que o livro situa-se no campo do livre debate de idéias, estando acobertado pela livre convicção político-ideológica, e a livre manifestação do pensamento. O paciente agiu no mundo das idéias, desenvolvendo tese baseada em pesquisas e documentos. Tentou convencer outras pessoas pela razão, com argumentos, e não incitar ódio. O Ministro ressaltou que os fatos históricos permitem diversas interpretações, e ter uma ideologia não é crime. Ainda, o paciente não deveria responder por obras de outros autores, que apenas são distribuídas por ele.

O Ministro Marco Aurélio também entendeu correta a concessão da ordem, mas com base em outros argumentos. Defendeu que a liberdade de expressão é essencial num Estado Democrático de Direito. E ao difundir outra versão da história, o paciente apenas exerceu seu direito de pensar diferente, o que não significa discriminar. A liberdade de expressão, pela sua importância, deve ser restringida somente em situações excepcionais, quando há claro abuso do direito (o que, para o Ministro, não ocorreu). Ademais, um livro, por si só, é incapaz de transformar a sociedade; seu papel é de convencer sobre uma determinada tese. Ressaltou, ainda, que a sociedade brasileira nunca discriminou ou teve a tradição de discriminar judeus. Enfim, concluiu o Ministro que a condenação proferida pelo Tribunal de Justiça do Rio Grande do Sul não foi adequada, necessária, nem razoável - ou seja, não aplicou bem o princípio da proporcionalidade para resolver a colisão entre a liberdade de manifestação e a dignidade do povo judeu.

Na decisão final atribuída pelo Supremo Tribunal Federal, no que concerne à liberdade de expressão, a ementa do julgado trouxe as seguintes considerações:

13. Liberdade de expressão. Garantia constitucional que não se tem como absoluta. Limites morais e jurídicos. $\mathrm{O}$ direito à livre expressão não pode abrigar, em sua abrangência, manifestações de conteúdo imoral que implicam ilicitude penal. 14. As liberdades públicas não são incondicionais, por isso devem ser exercidas de maneira harmônica, observados os limites definidos na própria Constituição Federal (CF, artigo $5^{\circ}, \S 2^{\circ}$, primeira parte). O preceito fundamental de liberdade de expressão não consagra o "direito à incitação ao racismo", dado

A\&C R. de Dir. Administrativo \& Constitucional, Belo Horizonte, ano 8, n. 32, p. 77-92, abr./jun. 2008 
que um direito individual não pode constituir-se em salvaguarda de condutas ilícitas, como sucede com os delitos contra a honra. Prevalência dos princípios da dignidade da pessoa humana e da igualdade jurídica. ${ }^{20}$

\section{A liberdade de expressão num contexto democrático}

A restrição de direitos fundamentais é possível e aceitável, afinal os direitos fundamentais não são absolutos nem ilimitados. Os direitos garantidos mediante princípios (como a liberdade de expressão) são necessariamente restringíveis, porque seu grau de aplicabilidade depende das condições fáticas e jurídicas que se apresentam no caso concreto.

É na medida das possibilidades fáticas e jurídicas que a liberdade deve ser protegida e promovida. Esse o sentido da expressão "mandado de otimização", de Alexy, para definir os direitos fundamentais de cunho principiológico: "princípios são mandados de otimização que estão caracterizados pelo fato de que podem ser cumpridos em diferentes graus, e que, a medida devida de seu cumprimento não só depende das possibilidades reais, senão também das jurídicas". ${ }^{21}$

Para além dos limites estabelecidos pela própria Constituição (limites internos), há limites externos advindos da vida em sociedade (ordem pública, moral, segurança, entre outros). "É neste sentido que se justifica a afirmação de que a perspectiva objetiva dos direitos fundamentais não só legitima restrições aos direitos subjetivos individuais com base no interesse comunitário prevalente, mas também que, de certa forma, contribui para a limitação do conteúdo e do alcance dos direitos fundamentais, ainda que deva sempre ficar preservado o núcleo essencial destes."22

Os direitos fundamentais possuem dupla dimensão, "na medida em que podem, em princípio, ser considerados tanto como direitos subjetivos individuais, quanto elementos objetivos fundamentais da comunidade". ${ }^{23}$ Assim, os direitos fundamentais podem exercer a função de direito subjetivo ${ }^{24}$ e de valores da comunidade juridicamente objetivados. Se o direito fundamental for considerado apenas na sua dimensão subjetiva, sua amplitude será muito grande. Como há uma dimensão objetiva, os direitos funda-

Justiça, Brasília, p. 17, 19 mar. 2004.

${ }^{21}$ ALEXY. Teoria de los derechos fundamentales, p. 86.

22 SARLET. A eficácia dos direitos fundamentais, p. 160. $23 \mathrm{lbid}, \mathrm{b} .155$

24 Para Canotilho, "uma norma garante um direito subjectivo quando o titular de um direito tem, face ao seu 
mentais não são pensados somente como posições jurídicas titularizadas por um indivíduo frente ao Estado, mas também como valores ou fins que a comunidade valoriza e protege (como direito objetivo).

E sendo também da coletividade, o direito não está no campo da livre disposição individual e não é absoluto, porque há outros bens a serem protegidos. Assim, pode ser restringido um direito se necessário para priorizar outro interesse com ele conflitante. Em verdade, as restrições são necessárias para a realização, na maior medida possível, de todos os valores caros à sociedade.

Tratando-se da liberdade de expressão, um dos pilares fundamentais dos sistemas democráticos — na medida em que permite o intercâmbio de idéias, o controle do poder, o diálogo político e inclusive a formação da identidade individual e coletiva —, discute-se se está sujeita também às limitações que podem ser impostas pelo Estado. Conforme aponta Roberto Saba, a partir de uma óptica liberalista, que entende a liberdade de expressão como uma liberdade exclusivamente negativa, é complicado justificar qualquer limitação a esse direito fundamental. ${ }^{25}$

Contudo, há uma segunda forma de entender a liberdade de expressão, que a associa com a necessidade de existir em um sistema democrático um robusto fluxo de idéias. Nesses termos, como a democracia é o sistema de autogoverno pelo qual a cidadania decide coletivamente quais são as regras vigentes na comunidade política, esse autogoverno acaba exigindo que a liberdade de expressão seja entendida não apenas como um direito à autodeterminação autônoma, mas sim como uma precondição do sistema democrático, pois incrementa e possibilita o intercâmbio de idéias e perspectivas. $^{26}$

Assim, com base nesse segundo enfoque, é possível restringir a liberdade de expressão e também é defensável uma regulamentação estatal do seu exercício que tenda a fortalecer o debate púbico. Restrições ao discurso

destinatário, o 'direito' a um determinado acto, e este último tem o dever de, perante o primeiro, praticar esse acto" (CANOTILHO. Direito constitucional e teoria da constituição, p. 1240). Vieira de Andrade parte da idéia comum de que "direito subjectivo implica um poder ou uma faculdade para a realização efectiva de interesses que são reconhecidos por uma norma jurídica como próprios do respectivo titular" (ANDRADE. Os direitos fundamentais na Constituição Portuguesa de 1976, p. 114).

${ }^{25}$ FISS; SABA. Contra-punto: el valor de la libertad de expresión. Disponível em: <http://www.udp.cl/derecho/ publicaciones/contra_owen.pdf>. Acesso em: 19 jul. 2007, p. 01. 26 bid., p. 02

27 Ibid., p. 03.

A\&C R. de Dir. Administrativo \& Constitucional, Belo Horizonte, ano 8, n. 32, p. 77-92, abr./jun. 2008 
racista, por exemplo, seriam justificáveis na medida em que retiram minorias do debate público, bem como restrições à pornografia, discurso que propaga a imagem da mulher como um objeto sexual e diminui sua capacidade de contribuir para a discussão pública. ${ }^{27}$

O que se defende é que, em um contexto democrático, o Estado, para preservar a discussão pública, pode restringir a liberdade de expressão calando discursos que calam. Trata-se da teoria de Owen Fiss sobre o efeito silenciador do discurso. Segundo o autor, há discursos que, quando proferidos, silenciam outros discursos, por conterem discriminação. E esses discursos silenciadores devem ser silenciados, para permitir que todos participem do debate. Os discursos de ódio (hate speeches) tendem a diminuir o valor das vitimas, impedindo, assim, a sua participação plena em muitas das atividades da sociedade civil. ${ }^{28}$

Então, o papel o Estado - e também da jurisdição constitucional — é o de preservar a solidez do debate público, assegurando as condições necessárias para o autogoverno da coletividade, mesmo que para tanto seja necessário restringir os discursos que apresentam um efeito silenciador. ${ }^{29}$

A metáfora apresentada por Saba é bem esclarecedora. Suponha-se que se esteja em uma sala de aula, na qual, utilizando-se do método socrático, todos os alunos possam apresentar suas idéias e pontos de vistas. Como a aula dura apenas duas horas, existem limites de tempo no debate. Afinal, não seria justo que um dos participantes falasse durante uma hora e meia e deixasse de lado o ponto de vista dos demais. Suponha-se ainda que na classe existisse um grande número de alunos e, dessa forma, apenas seriam ouvidos os que tiveram capacidade de adquirir um microfone. Nessa classe, noventa por cento das vozes pertencessem à maioria branca masculina, não sendo o contexto propício para a minoria indígena, homossexual e feminina manifestar sua opinião. Nessas condições, é exigível que o Estado atue distribuindo a palavra, o microfone, impondo limites às vozes mais poderosas e dando espaço para as manifestações mais frágeis, tudo com a finalidade de fortalecer o debate público e melhorar a qualidade das decisões de autogoverno. ${ }^{30}$

\footnotetext{
28 FISS. El efecto silenciador de la liberdad de expresión. Disponível em: < http://www.cervantesvirtual.com/servlet/ SirveObras/01474063322636384254480/isonomia04/iso03.pdf>. Acesso em: 17 jul. 2007, p. 22.

29 bid., p. 23

${ }^{30}$ FISS; SABA, op. cit., p. 04.
}

A\&C R. de Dir. Administrativo \& Constitucional, Belo Horizonte, ano 8, n. 32, p. 77-92, abr./jun. 2008 
Portanto, a liberdade de expressão não é absoluta, principalmente no Estado Democrático de Direito, e deve ser protegida nos exatos limites em que não se transforme em um elemento silenciador das demais manifestações.

\section{Considerações finais}

Diante dessas balizas - papel da jurisdição constitucional em um ambiente democrático e importância da liberdade de expressão para a democracia - o julgado do Supremo Tribunal Federal no caso Ellwanger, restringindo essa liberdade, teria sido legítimo?

Pode-se concluir que sim, pois ofensas ao povo judeu em nada contribuem para a democracia, não fomentam qualquer debate útil à sociedade. Ou seja, a liberdade de expressão exercida por Sigfried Ellwanger ultrapassou os limites da própria liberdade de expressão, transformando-se em um elemento silenciador que tem como único efeito reduzir a participação da comunidade judaica no discurso.

A liberdade de expressão não pode ser exercida com abuso, para proferir discursos de ódio e que silenciam outros discursos, como o discurso do povo judeu, que se torna enfraquecido. Assim, mais contribui para a democracia restringir uma expressão desrespeitosa do que permitir sua circulação ofendendo alguns grupos.

Considere-se, ainda, que todos os cidadãos devem ser tratados com o mesmo respeito e a mesma dignidade. Uma sociedade democrática é aquela em que há consideração e respeito mútuos, e não em que indivíduos dividem-se em superiores e inferiores. A liberdade de expressão é expressão de liberdade. E se há ódio e discriminação, certamente não há liberdade.

Atuando no sentido de restringir o discurso de ódio e silenciador, o Supremo Tribunal Federal, no exercício da jurisdição constitucional, agiu de forma legítima e condizente com as premissas democráticas.

Ademais, a decisão do Supremo Tribunal Federal no caso Ellwanger configura-se como uma das mais importantes jurisprudências brasileiras em matéria de direitos humanos, contribuindo para uma amadurecida reflexão sobre o racismo no país, que anseia por justiça social e respeito 
incondicional à dignidade da pessoa humana. Revela a interação entre o direito constitucional interno e o direito Internacional público, e mostra o compromisso dos julgadores com uma sociedade plural e ao mesmo tempo igual.

Abstract: This paper analyses the relation between judicial review, democracy and free speech in a democratic context. To achieve this research, it was elected the leading case "Ellwanger", judged by Brazilian Supreme Court in 2003.

Keywords: Judicial review. Free speech and democracy.

\section{Referências}

ALEXY, Robert. Teoria de los derechos fundamentales. Tradução Ernesto Garzón Valdés. Madrid: Centro de Estudios Constitucionales, 1997.

ANDRADE, José Carlos Vieira de. Os direitos fundamentais na Constituição Portuguesa de 1976. 2. ed. Coimbra: Almedina, 2001.

BOROWSKI, Martin. La estructura de los derechos fundamentales. Tradução Carlos Bernal Pulido. Bogotá: Universidad Externado de Colombia, 2003.

CANOTILHO, José Joaquim Gomes. Direito constitucional e teoria da constituição. 6. ed. Coimbra: Almedina, 2002.

CLÈVE, Clèmerson Merlin. Palestra. In: Discurso e direito: discursos do direito. Curitiba, 2006.

ELSTER, Jon. Introducción. In: ELSTER, Jon; SLAGSTAD, Rune (Org.). Constitucionalismo y democracia. Tradução Mônica Utrilla de Neira. México: Fondo de cultura econômica, 1999.

ELSTER, Jon. Ulises desatado: estudios sobre a racionalidad, precompromisso y restricciones. Tradução Jordi Mundo. Barcelona: Gedisa, 2002.

FARBER, Daniel; ESKRIDGE JUNIOR, William; FRICKEY, Philip. Constitutional law: themes for the constitution's third century. Minessota: West Publishing Company, 1993.

FISS, Owen. El efecto silenciador de la liberdad de expresión. Disponível em: < http://www. cervantesvirtual.com/servlet/SirveObras/01474063322636384254480/isonomia04/iso03. pdf>. Acesso em: 17 jul. 2007.

FISS, Owen; SABA, Roberto. Contra-punto: el valor de la libertad de expresión. Disponível em: <http://www.udp.cl/derecho/publicaciones/contra_owen.pdf>. Acesso em: 19 jul. 2007.

GARGARELLA, Roberto. La justicia frente al gobierno: sobre el carácter contramayoritario del poder judicial. Barcelona: Ariel, 1996.

HAMILTON, Alexander. Os juízes como guardiões da constituição. In: HAMILTON, Alexander; MADISON, James; JAY, John. O federalista. Tradução Heitor Almeida Herrera. Brasília: Ed. Universidade de Brasília, 1984.

HOLMES, Stephen. El precompromiso y la paradoja de la democracia. In: ELSTER, Jon; SLAGSTAD, Rune (Org.). Constitucionalismo y democracia. Tradução Mônica Utrilla de Neira. México: Fondo de Cultura Económica, 1999.

MORO, Sergio Fernando. Jurisdição constitucional como democracia. 2002. Tese (Doutorado

A\&C R. de Dir. Administrativo \& Constitucional, Belo Horizonte, ano 8, n. 32, p. 77-92, abr./jun. 2008 
em Direito do Estado) - Setor de Ciências Jurídicas, Universidade Federal do Paraná, Curitiba, 2002.

NINO, Carlos Santiago. Fundamentos de derecho constitucional: análisis filosófico, jurídico y politológico de la práctica constitucional. Buenos Aires: Astrea, 2005.

NINO, Carlos Santiago. La constitucion de la democracia deliberativa. Barcelona: Gedisa, 1997.

RAWLS, John. O liberalismo político. Tradução Dinah de Abreu Azevedo. 2. ed. São Paulo: Atica, 2000.

SARLET, Ingo Wolfgang. A eficácia dos direitos fundamentais. 5. ed. rev., atual. e ampl. Porto Alegre: Livraria do Advogado, 2005.

SUPREMO TRIBUNAL FEDERAL. Crime de racismo e anti-semitismo: um julgamento histórico no STF: habeas corpus n ${ }^{\circ}$ 82.424/RS. Brasília: STF, 2004.

VIEIRA, Oscar Vilhena. A constituição e sua reserva de justiça: um ensaio sobre os limites materiais ao poder de reforma. São Paulo: Malheiros, 1999.

Informação bibliográfica deste texto, conforme a NBR 6023:2002 da Associação Brasileira de Normas Técnicas (ABNT):

HONÓRIO, Cláudia; KROL, Heloísa. Jurisdição constitucional, democracia e liberdade de expressão: análise do caso Ellwanger. A\&C Revista de Direito Administrativo \& Constitucional, Belo Horizonte, ano 8, n. 32, p. 77-92, abr./jun. 2008. 